\title{
Cutaneous Metastases From Transitional Cell Carcinoma of the Renal Pelvis: A Case Report
}

\author{
Mitsuru Komeya a, c, Tamami Sahoda ${ }^{a}$, Shinpei Sugiura ${ }^{a}$, Takuto Sawada ${ }^{\text {a }}$ Kazuo Kitami ${ }^{\text {, }}$ \\ Youichi Iemoto $^{\mathrm{b}}$
}

\begin{abstract}
A 73-year-old female patient presented with left back pain. Computed tomography showed a mass around the left renal hilum and subcutaneous masses in her abdomen. She was referred to our hospital. Retrograde pyelography showed an upper urinary tract obstruction. Urinary cytology of the ureter was negative. Biopsy of the subcutaneous mass was performed, and the pathological findings showed transitional cell carcinoma. She was diagnosed with transitional cell carcinoma of the left renal pelvis with metastasis to the skin (cT4N0M1). She received combination chemotherapy, but the size of her skin lesions was increasing. Three months after admission, she died. Metastasis to the skin from the renal pelvis is very rare; only four cases have been reported. Our case is the first report on transitional cell carcinoma of the renal pelvic metastasizing to only the skin at presentation. We herein summarize this rare metastasis and discuss its clinical features and therapeutic management.
\end{abstract}

Keywords: Pelvic cancer; Renal pelvis; Transitional cell carcinoma; Cutaneous metastasis

\section{Introduction}

Cutaneous metastasis from internal malignancies is uncommon and occurs in $0.7 \%$ to $9 \%$ of patients with internal cancers. Stephen et al found 124 patients with cutaneous metastases among 12,146 patients with internal malignancies [1].

Manuscript accepted for publication October 4, 2012

${ }^{a}$ Department of Urology, Fujisawa City Hospital, 2-6-1 Fujisawa, Fujisawa, Kanagawa 251-8550, Japan

${ }^{b}$ Department of Pathology, Fujisawa City Hospital, 2-6-1 Fujisawa, Fujisawa, Kanagawa 251-8550, Japan

${ }^{\mathrm{c}}$ Corresponding author: Mitsuru Komeya, Department of Urology,

Fujisawa City Hospital, 2-6-1 Fujisawa, Fujisawa, Kanagawa 251-8550,

Japan. Email: urology_ycu@yahoo.co.jp

doi: http://dx.doi.org/10.4021/wjnu45w
In the study, only 2 patients had cutaneous metastases from genitourinary malignancies. The rate of cutaneous metastasis from genitourinary malignancies was $0.22 \%$.

More metastases from the urinary bladder than from the renal pelvis have been reported in the literature [2].

Metastasis to the skin from the renal pelvis is very rare, and only four cases have been reported [2-5]. Our case is the first report of transitional cell carcinoma (TCC) of the renal pelvic metastasizing to only the skin at presentation. We herein summarize this rare metastasis and discuss its clinical features and therapeutic management.

\section{Case Report}

A 73-year-old female patient presented with left back pain and subcutaneous abdominal nodules. The lesions were tender, firm, and fixed. A computed tomography scan showed a mass around the left renal hilum and subcutaneous abdominal masses (Fig. 1). She was referred to our hospital. Retrograde pyelography showed an obstruction in the upper urinary tract. Urinary cytology of the ureter was negative. Magnetic resonance imaging, gastrointestinal endoscopy, and colorectal endoscopy showed no other abnormalities. Biopsy of a subcutaneous mass was performed. The mass was $1.5 \mathrm{~cm}$ in diameter, yellowish-white, solid, and encapsulated (Fig. 2a). Pathological findings showed proliferation of atypical cells infiltrating the subcutaneous fat tissue in

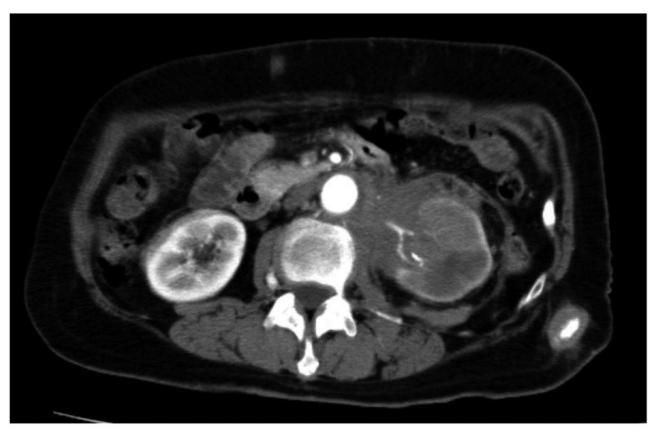

Figure 1. Computed tomography showed a mass around the left renal hilum and subcutaneous abdominal masses. 


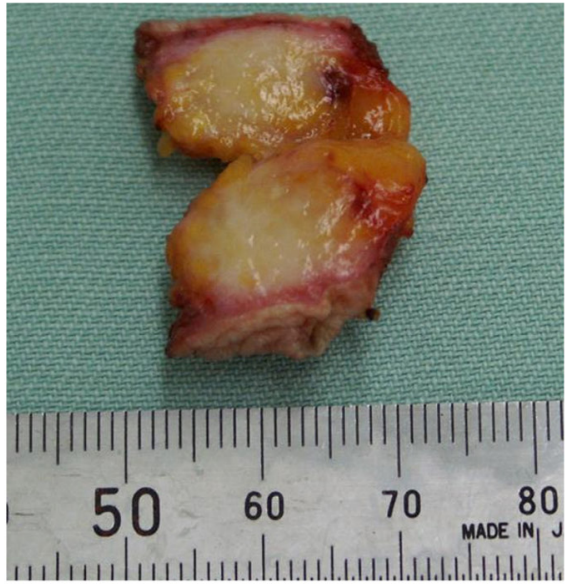

a

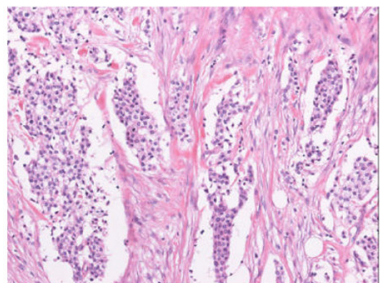

b

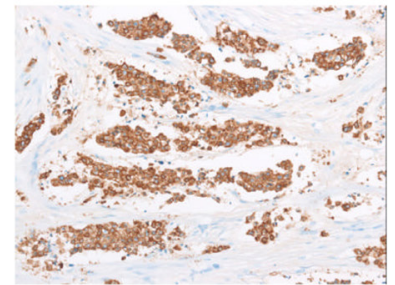

$\mathrm{C}$

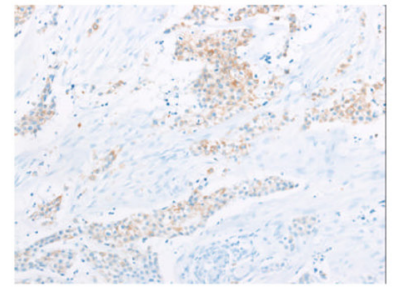

d

Figure 2. (a) The mass was $1.5 \mathrm{~cm}$ in diameter, yellowish-white, solid, and encapsulated; (b) Pathological findings showed a proliferation of atypical cells infiltrating the subcutaneous fat tissue in nests and cords throughout the dermis with no involvement of the overlying epidermis. (H\&E staining, $\times 200$ ); (c) Atypical cells were positive for CK7; (d) Atypical cells were positive for CK20.

nests and cords throughout the dermis with no involvement of the overlying epidermis. These atypical cells were positive for CK7 and CK20 (Fig. 2b, c, d). She was diagnosed with TCC of the left renal pelvis with metastasis to the skin (cT4N0M1).
The patient received combination chemotherapy comprising $30 \mathrm{mg} / \mathrm{m}^{2}$ methotrexate, $3 \mathrm{mg} / \mathrm{m}^{2}$ vinblastine, $30 \mathrm{mg} /$ $\mathrm{m}^{2}$ doxorubicin, and $70 \mathrm{mg} / \mathrm{m}^{2}$ cisplatin. However, the size of her skin lesions was increasing. Three months after admission, she died.

Table 1. Case Reports of Cutaneous Metastases From Transitional Cell Carcinoma of the Renal Pelvis

\begin{tabular}{|c|c|c|c|c|c|c|}
\hline Case & Author & Sex & Age & Initial Treatment & Adjuvant Therapy & $\begin{array}{l}\text { Duration } \\
\text { between } \\
\text { surgery } \\
\text { and skin } \\
\text { metastases } \\
\text { (month) }\end{array}$ \\
\hline 1 & Ando et al & male & 67 & nephroureterectomy & chemotherapy & 27 \\
\hline 2 & Chitale et al & male & 68 & nephroureterectomy & none & 2 \\
\hline 3 & Zirwas et al & male & 43 & nephroureterectomy & none & 48 \\
\hline 4 & Lin et al & female & 68 & nephroureterectomy & $\begin{array}{l}\text { chemotherapy }+ \\
\text { radiation therapy }\end{array}$ & 18 \\
\hline 5 & our case & female & 73 & none & none & 0 \\
\hline
\end{tabular}


Table 2. Case Reports of Cutaneous Metastases

\begin{tabular}{|c|c|c|c|c|c|c|}
\hline Case & $\begin{array}{l}\text { Appearance of skin } \\
\text { metastasis }\end{array}$ & $\begin{array}{l}\text { Distribution of } \\
\text { skin metastases }\end{array}$ & $\begin{array}{l}\text { Other } \\
\text { metastatic } \\
\text { regions }\end{array}$ & Treatment & Outcome & $\begin{array}{l}\text { Follow-up } \\
\text { (month) }\end{array}$ \\
\hline 1 & zosteriform & left chest wall & $\begin{array}{l}\text { left axillary } \\
\text { LN }\end{array}$ & $\begin{array}{l}\text { chemotherapy }+ \\
\text { radiation therapy }\end{array}$ & alive & 10 \\
\hline 2 & unknown & $\begin{array}{l}\text { back, abdomen, } \\
\text { limbs }\end{array}$ & lung, brain & none & dead & 1 \\
\hline 3 & $\begin{array}{l}\text { vascular-appearing } \\
\text { nodule }\end{array}$ & shoulder & $\begin{array}{l}\text { sacroiliac } \\
\text { area, lung }\end{array}$ & chemotherapy & unknown & unknown \\
\hline 4 & nodular & arm, abdomen & $\begin{array}{l}\text { local, liver, } \\
\text { left kidney }\end{array}$ & none & dead & 1 \\
\hline 5 & nodular & abdomen & none & chemotherapy & dead & 3 \\
\hline
\end{tabular}

\section{Discussion}

Cutaneous metastasis from TCC of the genitourinary system is rare. Most metastases originate from the urinary bladder. The rate of cutaneous metastasis from the urinary bladder ranges from $0.2 \%$ to $2.0 \%$ [2]. However, the rate from the renal pelvis remains unknown, and only four cases have been reported in the literature [2-5].

We summarized the characteristics of five patients with TCC of the renal pelvis and metastasis to the skin (Table 1, 2). The median age of these patients was 68 years. Three patients were male and two patients were female. Their pathological stage and grade were unclear. Four patients, excluding ours, underwent radical nephroureterectomy before the metastasis to the skin. Two patients received adjuvant therapy, one received chemotherapy, and one received a combination of radiation and chemotherapy. The median interval from surgery to metastasis was 22.5 months (range, 2 - 48 months).

Metastasis to the skin occurs as a result of direct infiltration and lymphatic or hematogenous dissemination. Carcinomas of the breast and oral cavity often involve the locoregional skin through lymphatic routes. Other carcinomas often involve any area of the skin, including sites distant from the primary tumor, as a result of hematogenous dissemination [6].

We did not identify the pathological mechanism of metastasis in our case. However, there were multiple and distant subcutaneous metastases, including in the head. Hematogenous dissemination may play an important role in metastasis.

The pattern of the metastatic skin lesions varied; three were nodules, one was zosteriform metastasis, and one comprised vascular-appearing nodules.
TCC of the renal pelvis metastasized to various areas of the skin, specifically the shoulder, chest, back, abdomen, limbs, and arm.

All patients except ours had multiple metastatic lesions in various organs: the brain, lung, lymph node, liver, and contralateral kidney.

In the present case, we could not obtain specimens from the primary lesions. Immunohistochemical staining was required to determine the primary origin. The differential expression of CK 7 and CK20 is useful in the differential diagnosis of various metastatic carcinomas of epithelial origin. TCC commonly demonstrates both CK 7 and CK20 positivity $[7,8]$. Pancreatic carcinoma, cholangiocarcinoma, and some gastric carcinomas also commonly show co-expression of CK 7 and CK20 [8]. These carcinomas must be excluded by diagnostic imaging.

Therapeutic treatment for TCC of the renal pelvis with metastasis to the skin was limited. Two patients received chemotherapy, and one received a combination of radiation and chemotherapy. After the metastasis to the skin was diagnosed, their median survival time was only 2 months (range, 1 - 10 months). Skin metastases may be a sign of a poor prognosis. However, one patient who received chemotherapy and radiation therapy remained stable for 10 months. Although no effective treatment can be recommended, we may attempt early commencement of chemotherapy because it provides a chance to control disease. If metastatic lesions are localized, additional radiation therapy may be worth consideration.

Unfortunately, if performance status is so bad that patients cannot receive any therapeutic treatment, patients or their families should be informed about their extremely poor prognosis so that they may choose how they spend the rest of their life and receive optimal palliative care. 


\section{Conflicts of Interest}

None declared.

\section{References}

1. Hu SC, Chen GS, Wu CS, Chai CY, Chen WT, Lan CC. Rates of cutaneous metastases from different internal malignancies: experience from a Taiwanese medical center. J Am Acad Dermatol. 2009;60(3):379-387.

2. Ando K, Goto Y, Kato K, Murase T, Matsumoto Y, Ohashi M. Zosteriform inflammatory metastatic carcinoma from transitional cell carcinoma of the renal pelvis. J Am Acad Dermatol. 1994;31(2 Pt 1):284-286.

3. Chitale SV, Morrow DR, Patel R, Gaches CG, Ball RY. Cutaneous metastases from transitional cell carcinomas of the bladder and renal pelvis. Br J Urol. 1997;79(2):292-293.
4. Zirwas MJ, Hunt S, Logan TF, Abernethy JL, Seraly MP. A painful cutaneous nodule as the presentation of metastatic transitional cell carcinoma of the renal pelvis. $\mathrm{J}$ Am Acad Dermatol. 2000;42(5 Pt 2):867-868.

5. Lin CY, Lee CT, Huang JS, Chang LC. Transitional cell carcinoma metastasis to arm skin from the renal pelvis. Chang Gung Med J. 2003;26(7):525-529.

6. Elder DE, Elenitsas R, Johnson BL, Murphy GF, Xu $\mathrm{X}$. Lever's histopathology of the skin 10th edition, Lippincott-Williams \& Wilkins, Philadelphia, 2008, p1151-59.

7. Jiang J, Ulbright TM, Younger C, Sanchez K, Bostwick DG, Koch MO, Eble JN, et al. Cytokeratin 7 and cytokeratin 20 in primary urinary bladder carcinoma and matched lymph node metastasis. Arch Pathol Lab Med. 2001;125(7):921-923.

8. Chu P, Wu E, Weiss LM. Cytokeratin 7 and cytokeratin 20 expression in epithelial neoplasms: a survey of 435 cases. Mod Pathol. 2000;13(9):962-972. 